\title{
TEOLOGH PRAKTYCZNA
}

UNTWERSYTET IM. ADAMA MICKIEWICZA - WYDZLAL-TEOLOGICZNY

\section{TOM 3,2002}

\section{ADAM KALBARCZYK}

\section{Fazy życia grup parafialnych}

Każda grupa chce zwykle - choć na początku często nieswiadomie - przekształcić się z luźnego, mniej lub bardziej przypadkowego związku w solidarną i organiczną wspólnotę, głębokie, doniosłe i autentyczne spotkanie osób. Dzieje się tak, gdy członków grupy jednoczą wspólne cele i dzialania, a przede wszystkim osobowe. braterskie, przyjacielskie relacje. Na drodze do tego celu grupa musi przejşć różne etapy.

Literatura fachowa wylicza i opisuje rozmaite fazy życia małych wspólnot. Niniejszy artykuł jest próbą systematyzacji tych opisów. Ma on pomóc we wniknięciu w realia, dzieje małych wspólnot chrzescijańskich, a przez to w odnalezieniu perspektyw dla swiadomej i ukierunkowanej pracy z grupami w duszpasterstwie parafialnym. Zamieszczony poniżej opis faz rozwojowych grupy ma jednak nadal charakter przykładowy i nie stanowi wzorca, według którego proces grupowy musi przebiegać. Rzeczywistość jest znacznie bogatsza i o wiele bardziej złożona niż jakikolwiek linearny schemat. Wyróżnione tu fazy mogą w praktyce przebiegać nieco inaczej lub następować po sobie w innej kolejnosci. Każda grupa jest inna, a w jej rozwoju mogą zaistnieć przeskoki z fazy wcześniejszej do fazy (dużo) pó́niejszej albo powroty do fazy wcześniejszej. Ponadto nie wszyscy czlonkowie grupy przeżywają poszczególne fazy jednocześnie. Trzeba pamiętac, że na rozwój grupy wpływa wiele rozmaitych czynników, pośród których istotną rolę odgrywa stopień uwzględnienia tkwiącej w każdym człowieku potrzeby uznania, przynależności i bezpieczeństwa.

\section{Proces grupowy i jego fazy}

Proces grupowy jest tym wszystkim, co dzieje się, dokonuje się w grupie w odniesieniu do jej zadań. Można go pojmować także jako drogę do celu (celów) grupy. Grupa przemierza tę drogę w atmosferze grupowej, która zależy od wielu czynników. Niektóre z nich, jak np. liczba uczestników, ich wiek i płeć, czas istnienia grupy, styl 
kicrowania grupą są zmienne. Inne natomiast, jak np. biografie członków grupy, ich witalność, tło kulturowe, aktualna faza rozwojowa grupy nie dają się zmienić. Poddawanic refleksji, artykułowanie, integrowanie i wykorzystanie róznych racjonalnych i subracjonalnych (potrzeby, oczekiwania, lęki) sil, które obecne są w każdej grupie jako pewnej liczbie jednostek uczestniczących w procesic bezpośredniej komunikacji, będących we wzajemnej zależności i zmierzających do wspólnego celu, umożliwia funkcjonowanie grupy. Mamy tu do czynienia ze swoistą grą sil która określana jest jako dynamika grupowa. Opiera się ona na bodźcu i sterowaniu, które sprzężone ze sobą tworzą podstawowe czynniki procesu grupowego.

Proces grupowy jest rozwojem i jako taki składa się z różnych faz. Zanim grupa zacznie efektywnic realizować swoje cele, musi przebrnąć przez pełną konfliktów fazę wstępnq. Odnosi się to do każdej grupy. Proces grupowy zawiera z pewnością także i regularnie występujące fazy kryzysu i zróżnicowanej pod względem nasilenia w grupie jako calości $i$ w każdym jej czlonku z osobna regresji, powrotu do wcześnicjszych, mniej zróżnicowanych zachowań.

Próby wyodrę̧nicnia faz procesu grupowego zrodzity liczne ich modele. Zwykle jednak odnoszą się one do określonych typów grup i odzwierciedlają pewien punkt widzenia. Np. psychologia spułcczna, dla której proces grupowy to przejście od syłuacji gnupowej jako jedynie „otoczenia" dzialań indywidualnych do mikrosystemu, zakladającego dlugotrwałc interakcje, wyróżnia cztery wzglçdnie pięć faz: forming (formowanie się grupy), storming (okres „burzy i naporu”), norming (ustalanie norm), performing (ukierunkowanic na zadania) i ewentualnie adjouming (rozwiązanie się grupy $)^{2}$. W terapii grupowej obowiązuje model czterofazowy: faza wstepna lub przygotowawcza, faza akcji, faza integracji i faza nowej orientacji $i^{3}$. Model ten występuje w psychodramie, klasycznym dramacie oraz we wszystkich procesach twórczych i rozwiązania problemów. H. Petzold nazywa go modelem terradycznym ${ }^{4}$, modelem cztcrostopniowym. W fazie wstępnej zbierany jest materiał. Fazę akcji charakteryzują silne cmocje i punkty kulminacyjne, które zostają racjonalnie wyjaśnione i uporząukowane w fazie integracji. Rezultatem tego procesu jest nowa strukturalizacja i orientacja życia. Również i w liturgii oraz każdym doświadczeniu religijnym mamy do czynienia z podobnym przebicgiem. Jako przyklad można podać grupy charyzmatyczne, w kıórych chodzi o przejście od bardzo intensywnych uczuć religijnych do przemiany życia

' O. Hürter: Gnuppendynamik. W: Handbuch der Pastoraltheologie. Lexikon der Pastoraltheologie. Red. F. Klostermann i in. Freiburg 1972 s. 190.

'E. H. Witte $i$ in.: Gruppe. W: Wornerbuch der Soziulogie. T. 1. Red. G. Endruweit $i$ in. Sturtgart 1989 s. 255; por. M. Allemann: Gruppendynamik. W: Handlexikon zur pädagogischen Psychologie. Red. H. Schiefcle i in. München 1981 s. 156-157; por. H. Crott: Soziale Interaktion und Grippenprozesse. Stuttgart 1979 s. 220.

${ }^{3}$ K. Gastgeber: Gestalt-Gnuppenarteit als Hilfe für die Seelsorge. W: Glaube und Gruppe. Probleme der Grippendynamik in einem religiösen Kontext. Red. J. Scharfenberg. Wien - Gürtingen 1980 s. 86.

4 Tamże; więcej na ten temat W: Psychotherapie und Körperdynamik. Red. H. Petzold. Paderborn 1977: Tenze: Psychodrama als Instrument der Pastoralhierapie, der religiösen Selbsterfalınung und der Seelsonge. "Wege zum Menschen" nr 24 (1972) s. 41-S6; M. Moser: Zum methodischen Vorgehen im Bibliodrama. "Lebendige Seclsorge" nr 3 (1995) s. 149-153. 
i nowego bycia chrześcjaninem. D. Stollberg przedstawia rozwoj grupy w następujący sposób: faza ostrożnego przytaczania się i braku orientacji, faza identyfkacji i rywalizacji, faza konfrontacji i kooperacji, faza autonomii i faza rozstonias. Poszczególne fazy niekoniccznie musza następować po sobie jedna po drugicj, tzn. jedna faza nie musi wyzwalaé następnej. Chodzi tu raczej o ich ciagta utajonq obecność $\mathrm{i}$ jawnq dyspozycynośc w konkretnych sytuacjach grupowychí. Zwykle efcmenty różnych faz splatają̧ się, zazębiają̧ się ze sobą i przenikają sįę nawzajem.

\section{Model rozwoju grup parafialnych}

Opisany poniżej model rozwoju grup parafialnych opiera się czę́ciowo na projekcie pastoralnym Kóciót nadzici dia świata ${ }^{7}$, któny został opracowany w latach siedemdziesiątych $\mathrm{j}$ osiendziesiątych minionego wieku przez kilka wloskich parafii. Pomoze nam to spojrzeć na rzeczywistośc malych grup koscielnych nie tylko przez pryzmat psychologit, socjologii i pedagogiki, lecz także teologii pastoralnej. Opcji tej służą też przytoczone tutaj liczne przykłady z praktyki duszpasterskiej, z życia małych wspólnot chrześcijañskich:

\section{Fuza wstępna - wezwanie do tworzenta wspólnoty}

Uważa siç, że proces powstawania grupy zaczyna się wtedy, gdy jej potencjalni czlonkowie pragną osiągnąć cele, które dają się zrealizowac szybciej, lepiej lub wyIącznie w grupie. Jesli to zatożenie umiescimy perspektywie psychologicznej i socjologicznej, ukazującej czlowieka jako istotę społeczna i urzeczywistnająeą się poprzez przynaležnoł́c do przeróżnych i wzajemnie się uzupełniających wspólnot, to whaśnie owa samorealizacja — swiadoma czy nieświadona - zdaje się bye - abstrahujac od wszelkich bardzo konkretnych cel6w - głownym i najlepicj lub wylączje w grupie osiagalnym celem wszystkich potencja Inych jej czlonków. Odpowiada to także ujęciu teologicznemu: czlowiek będący cialem, dussą i duchem, egzystuje jako otwarty system, system pośród systemów, które spotykają się ze sobą. Poprzez wytyczenie wytánej granicy między tym co wownątrz a tym co nă zewnątrz tworzy się osobowa

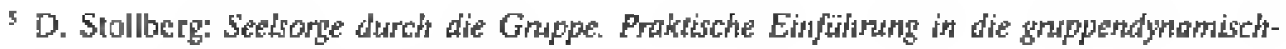
wherapewitrche Antilsweise. Güttinges 1971 s. 83.

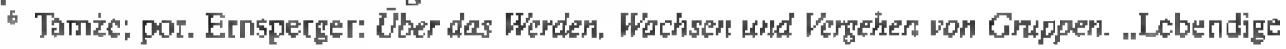
Seelsorget in 2 (1992) s. 100-105.

7 J. B. Cappellaro i in.: Kirche der Hoghtung fur de Welt. Eit Porsoral-Projekt. Thas 1985; por. J. B. Cappel]aro: PJamgemeinde der Zukunft. Eime Gemeinschaft der Gemeinschafien, Thaur 1979;

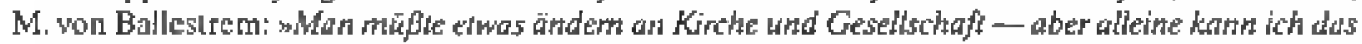

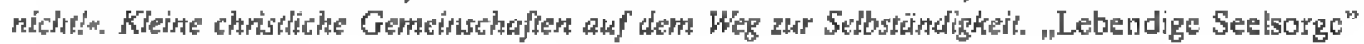
II 2 (1995) \& $71-74$.

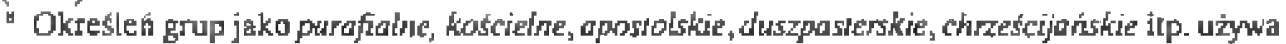

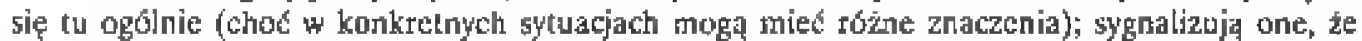
chodzi tu o grupy żjace i dzjałajace w prestreni koscielncj, pardfialno-dusapasterskicj (choc preciez nie maszį się do nicj ograniczać). 
tożsamość człowieka, która będzie tym wyrazistsza, im bogatsze i głębsze będą jego kontakty $\mathbf{z}$ innymi osobami'. Relacja jednej osoby ludzkiej do innych osób ludzkich zależy od ich odniesienia do Osoby Boskiej. Co prawda między Bogiem a czlowiekiem przebiega granica absolutna, ale w Jezusie dokonała się redukcja Bożej niedostępności. Św. Grzegorz z Nazjanzu powiedział, że Bóg stał się w Jezusie człowiekiem, aby człowiek mial dostęp do Boga. We wcieleniu Boga ujawniła się Jego milość do człowicka. Czlowiek ma kochać Boga, a otrzymany od Niego dar milości dawać innym. Relacja Jezusa do Ojca i Jego pełne milości odniesienie do człowieka ukazują całkowicic nową zasadę życia. Triada relacji ja - ry-Bóg tworzy dojście do prawdziwego, pełnego życia. Jeśli odniesienia do Boga, do drugiego czlowieka lub do siebie samego są zakłócone, to dostęp ten pozostaje zamkniçty. Dopiero w spotkaniu z ty człowiek odkrywa samego siebie, uczy się brać i dawać. Każde ludzkie ty wskazuje na większe $T y$, na Boga. Jedynie poprzez to potrójne odniesienie i zachowywanie Jezusowego przykazania milości Boga i bliźniego Kościół pierwotny utrzymal się przy życiu. Tylko poprzez bliźniego, poprzez tę dynamicznq dwoistosć, poprzez pytanie i odpowiadanie, dawanie i branie, szukanie i odnajdywanie siebie, jak formuluje to K. Gastgeber $^{10}$, czlowiek może być świadom wlasnej istoty, tylko przez to może się realizować, rozwijać, odnawiać, przemieniać, zdrowieć, stawać się człowickiem.

Odkrycie i wyartykułowanie prawdy, będącej przecicż podstawową prawdą chrześcijańską: zbawienie leży we wspólnocie, lub po prostu tęsknota za autentyczną wspólnotą może być powodem przyłączenia się jednostki do jakicjś grupy względnie do utworzenia przez nią jakiejś grupy. Wiele grup zawiązuje się mniej lub bardziej spontanicznie; rodza je spotkania, okoliczności, potrzeby egzystencjalne lub po prostu życie. Mogą być też świadomie powoływane do życia i sterowane w swoim rozwoju. Jednakże dążąc do posiadania grup w parafii należy pamiętać, że chodzi tu nie tylko o instalowanie, lecz także o dopuszczenie samodzielnego tworzenia się grup w myśl zasady samoorganizacji potrzcb (zwlaszcza religijnych). W jednym i drugim przypadku musi dojşć do uświadomienia sobie i doświadczenia wyrażonej wyżej podstawowej prawdy, jeśli potencjalni członkowie grupy nie chcą byé jedynie fizycznym związkicm indywiduów.

Przykladowo grupa świadcząca pomoc osobom w żałobie ${ }^{11}$ może zostać założona właśnie przez ludzi, którym śmierć zabrała kogoś bliskiego i którzy w kontekście swojej wspólnoty wiary, swojcj parafii pragną wypowiedzieć swój smutek, dopuścić łzy i znaleźć przy tym zrozumienie i oparcie, pokój i bliskośc, których aktualnie tak bardzo potrzebują. Grupa taka może być też powołana do życia przez ludzi, którzy doświadczyli w grupie wsparcia w żałobie i teraz sami na podstawie swojego pozytywncgo doświadczenia chcą pomagać innym ludziom w żałobie. Nadal jednak to duszpasterz jest tym, kto zgodnie $z$ ogólnymi oczekiwaniami, swoimi możliwościami, wyksztalceniem i przygotowaniem otacza lub powinien otaczać opicką ludzi oplakujących śmierć swoich bliskich. Ale zwykle nie może temu w pełni sprostać z powodu

- K. Gastgeber, dz. cyt., s. 83.

to Tamż, s. 88-89; por. M. Buber: Ich und Du. Heidelberg 1983.

"Zob. W. Müller: Gemeinsam wachsen in Gnuppen. Mainz 1989. 
wielu innych zadań i wczcśniej czy później będzic musiał - jeśli jest to dla niego ważne i jeśli nie chce poprzestać na sporadycznych kontaktach — pomyśleć o stałych grupach parafialnych pomagających osobom w żałobie. Trzeba jednak dążyć do tego, by proboszcz tworzył taką grupę lub w ogóle grupy, nie tylko dlatego, że zmuszają go do tego okoliczności albo że spodziewa się przez to znacznego osobistego odciążenia, lecz przede wszystkim dlatcgo, żc zależy mu na zintegrowanej, żywej wspólnocie parafialnej. $Z$ jego więc inicjatywy — tak dzieje sį̧ najczęsciej - mogą powstawać takie i wszystkie inne grupy. Do udziclania się w takich grupach względnie do współpracy z nimi można zachęcić psychologów i terapcutów, pracowników socjalnych i ewentualnie pielęgniarki i lekarzy. Może się zdarzyć, że to oni wyjdą z inicjatywą utworzenia takiej grupy.

Iskrą zapalną w procesie powstawania grupy, możc być jakieś będące udzjalem wiclu osób niecodzienne wydarzenie, które daje przedsmak glçbi i bogactwa, jakie kryje w sobie ludzka wspólnota. Zwykle jest to jakiś wstrząs, głçbokic ludzkie i religijne doświadczenie, pierwotne odkrycie owej sformulowanej wyżej prawdy: zbawienie leży we wspólnocie, a które w wielu ludziach budzi pragnienie stworzenia grupy. Oczywiście nickiedy o powstaniu grupy decyduje zwykły przypadek, ale pragnienie stworzenia wspólnoty może być teź świadomie wywolane. Np. jeden z czlonków rady parafialnej, który zajmował siç kiedyś jako student teatrem amatorskim, wyraża chęć przygotowania prıedstawienia z okazji jubileuszu pięćdziesięciolccia istnienia parafii. Zna w parafii ludzi, którzy - jak przypuszcza - mają takie same zainteresowania i cwentualnie wzięliby udział w realizacji jego zamierzeń. Zaprasza ich więc na spotkanie. Wielu z nich przychodzi, a niektórzy przyprowadzają jeszcze inne zainteresowane osoby. Czynią to być może z ciekawości względnie spodziewając się czegos, co sprawi im przyjemność lub okaże się w czymś pomocne. Po paru tygodniach konstytuuje się zespól, który przygotowuje wybraną wspólnie sżtukę teatralną i wystawia ją w dniu parafialnego jubileuszu. Zcbrane podczas prób i występu doświadczenia, niezapomniane wrażcnia i pozytywny oddźwięk w parafii rodzą u większości z uczestników pragnienie dalszych spotkań; chcą także i w przyszłości zbierać podobne doświadczenia, kıóre okazały się ubogacające; pragną być grupą, która poprzez wystawiane sztuki glosi też slowo Boże.

Takie wezwanie do tworzeniu wspólnoty może się rozlegać przy okazji różnych akcji w parafii, rekolekcji, misji ludowych, w trakcie przygotowania do synodu diecezjalnego, w ramach ksztalcenia dorosłych, podczas festynu parafialnego itp. Doskonałą okazją do tworzenia grup jest też katecheza parafialna, np. przygotowanie dzicci do Pienwszej Komunii św., młodzieży do bierzmowania czy dorosłych do chrztu. Istniejące w ramach tego przygotowania grupy mogą po przyjęciu sakramentów cgðystować dalej lub przeksztalcać się w nowe. Może być też i tak, że osoby te właśnie poprzez katechezę sakramentalną zbliżą się do swojej parafii (do czego należało by dążyć!) i przyłączą się do istnicjących w nicj grup (np. dzieci pierwszokomunijne mogą zostać ministrantami; młodzież bierzmowana może stworzyć zespół muzyczny, scholę itp.). Wszystko to wymaga akcji informacyjnej (wieczór informacyjny, ulotki do rozdania lub wyłożenia $w$ kościele $z$ informacją na temat wszystkich grup działajacych w parafii itp.). 
Nie wolno pominąc tu tych krę̧ów, których istnienic w parafii jest niemalze oczywiste, a które w praktyce moga zic być autentycznymi grupami. Np. sam podzial ministrantów na grupy, nie zawsze oznacza, że spotykają się oni regularnie i tworza mate wspólnoty, w ktörych się rozwijaja, wzrastają w wierze, uczą się j dzialają. Podzial na grupy ma nicjednok rotn te charakter czysto techniczny, zapewniający jedynic sprawne pehnienic slużby przy oltarzu. Zniana tego stanu rzecry zalezy w pierwszym rzędzie od proboszcza lub duszpasterza mbodziezy. Nie wystarczy jednak przydzielic kazdej gnipie lidera i zobowiązać je do regularnych spotkań. Przede wszystkim trzeba opracować koncepcje pracy z ministrantami. To jednak nie powinno dokonywać się bez udziału samych zainteresowanych; wycieczka, zcbranie plenarne lub spotkanie z rodzicami moga ujawnić takie czy inne oczekiwania j zyczenia otaz prcynieść konkretne pomysly co do dalszej pracy z ministrantami. Warto tez w tym celu whączać grupy ministranckie do udział’ w różnych akcjach kościelnych. Podobnie rzecz ma siç z kręgani lektorów i nadzwyczajnych szafarzy Eucharystii, które spotykają się parę razy w roku, by ustalić plan swojcf słuźby, rozwiązać jakieśs problemy liturgiczne lub organizacyjne, ewcntualnic wystuchać konferencji księdzáa-opiekuna albo wspólnie odmówic Nieszpory. I do tych krectów powinno być skierowane wezwanie do tworzenia wspólnoty. Dotrzeć ma ono też do czlonków rady parafiatnej, którzy np. poprzez wspólnie spędzony weekend thoga się wzajemnie lepiej poznać i rozaijaé niezbędne we wspolnocie poczucic owego my.

Punktem wyjścia wszystkich tych wspólnototwótczych dzialań musi być zawsze konkretny czlowiek. Jedynie solidaryzowanie się z pojedynczym człowiekiem, poszanowanie jego osobistych wartości, doświadczen i kryteríw, które muszą zostać odkryte, wzajeme otwarcic siç na sicbee, poświęcanie sobie czasu umożliwiają autentyczne spotkanie osób. Nigdy nie wolno nikomu narzucać gotowych schematów i ustaJonych z góry celow. Zachowanie Jezusa w Spotkaniu z Samarytanką (J 4, 1-26) jest wzorem ala wszystkich, którzy chca budowate wspólnotę: Jezus zwróll sie do rej kobiety, wyszedl od jej konkretnego doswiadczenia i stopniowo doprowadzil ja do wiary, nawrócentia, a w koncu do gotowós do apostolat ${ }^{12}$. Jesli chcemy tworzyc grupy, które sa od samego początku ukicnukowane na z góry ustalony cel lub zadanje i stosują określoną metode oraz stawiają konkretne warunki potencjalnym czlonkon, to nalezy rozpoczac ten proces od rzetelnej informacji na temat setsst istnicnia tych grup. W ten sposób unikniemy nieprozumień. Eepiej jest jednak zwrócić siç bezpośredtrio do tych czy innych osób lub środowisk, niż zawrzeć wszelkie potrzebne dane w jakimś piśmie względnie ogloszeniu. Np. w przypadku grap spotkaniowych ${ }^{13}$ tzeba na samym początku wyraźnie zaznaczyć, że nie są to grupy terapeutyczne, że w takich grupach spotykaja się ludzie zdrowi, którzy pragną poznat lepicj siebie i innych, jak też ubogacić swoje żcic lub jakieś jego wymiary oraz przeżywać je bardziej intensywnic. Grupy spotkaniowe w przestrzeni koscielnej mogą byc tworzone w róźnych

12 J. B. Cappollaro i in., diz. ol., s. 195 [wishstkje glaty z aiem. thum. AK].

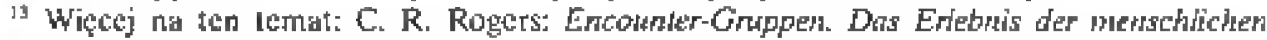

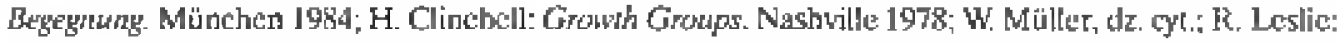

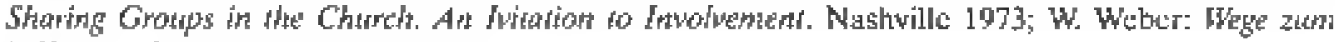
delferden Gespräch. Mïnchen 1982. 
celach, np. rozwiązywanie problemów małżeńskich, pokonywanie trudności z wiarą, radzenie sobie z doświadczeniem samotności, rozląki, śmierci kogoś bliskiego, poszerzanie kompetencji rodzicielskich itp.

Jeśli chcemy w duszpasterstwic grupowym wyjsć poza obszar środków konwencjonalnych i stosować wypróbowane już $\mathrm{i}$ niewątpliwie bardzo pomocne w terapii grupowej metody dynamiki grupowej, to wtedy trzeba mieć swiadomośc tego, że wymaga to wiclkiej odpowiedzialności i ostrożności, a przede wszystkim należytego przygotuwania. W przeciwnym razie będzie to ekspenymentowanie na czlowieku, które - zamiast ulcczyć - wpędzić może go w chorobę, glęboki kryzys psychiczny bądź uzależnienia ${ }^{\text {i4 }}$.

Jedynie wtedy, gdy sami sobie wyznaczamy granice, możemy wnikać w gląb rzeczywistości. Tylko w wyraźnie określonej, przejrzystej przcstrzeni można być rzeczywiście obecnym i bezpośrednio komunikować się z innymi. W przypadku niektórych rodzajów grup bardzo ważna jest zamknięta przestrzeń, chroniąca je przed ewentualnymi zakłóceniami z zewnątrz. Niemniej każda grupa potrzebuje własnej przestrzeni, w której spotykają się jej czlonkowie, gdzie są u siebie. Ta odgraniczona przestrzeń ma służć rozwojowi grupy - zwłaszcza w jego pierwszej fazie - a nie odgrodzeniu jej od otoczenia, od wspólnoty parafialnej.

Żeby powstała grupa, w której każdy ma swoje miejsce i w której panuje atmosfera wzajemnej akceptacji, należy zwrócić uwagę na to, by liczba jej członków była względnie mała. Jeśli to możliwe, nie powinna przekraczać 12 osób i być mniejsza niż 5 osób. Grupy, które składają się z mniej niż 5 osób, stwarzają zbyt mało okazji do osobistego wzrostu poprzez spotkanie z różnymi osobami, konfrontację z różnymi doswiadczeniami, perspektywami i systemami wartoscils. W grupie pięcioosobowej proces grupowy zostanie zakłócony już wtedy, gdy z jakichś powodów na spotkanie nic przyjdzie jeden z jej członków. Natomiast przy więcej niż 10 osobach sytuacja w grupie staje się nicprzcjrzysta. Przy wprowadzaniu nowych czlonków należy pamiętać, że każdy z nich zmienia sytuację i dynamikę grupową. Przy ich doborze warto zwracać nieco uwagę na różnice wieku, chó́ nie jest to warunek sine qua non. Decyduje o tym zawsze cel istnienia grupy. Np. w grupie dla par matźcńskich róźnice wicku zwykle nie mają większego znaczenia. Inaczej będzie w przypadku grup ministranckich. Mnicj więcej ten sam wiek jest tu obok „bycia ministrantem” wspólną plaszczyzną spotkania poszczególnych członków grupy. Dziewięciolatkowie nie będą mieli wicle wspólnego z szesnastoletnimi seniorami. Dobór czlonków wedlug plci stosuje się jedynie w grupach, w których płeć odgrywa zasadniczą rolę, np. w chórze chlopięcym czy męskim, w grupie dla samotnie wychowujących matek, gospodyń domowych itd.

14 Więcej na ten temat: J. Scharfenberg: Guppendynamik hat eine religiöse Dimension. W: Glaube und Gruppe, dz. cyt., s. 9-12; O. Betz: Intentionen und Methoden der Gruppendynamik. W: Die Gruppe als Weg. Einfühnung in dic Gruppendynamik und Religionspädagogik. Red. Tenze i in. München 1973 s. 29-40; B. J. Strojnowscy: Dynamika grupowa i jej zastosowanie w duszpasterstwie. W: Wybrane zagadnienia z psychologii pastoralnej. Lublin 1989 s. 103-121.

is Por. H. Clinebell, dz. cyt., s. 21. 
Jak zachowują się ludzie, którzy tạczá się w grupę lub w nią wchodzą? Co okrçsla ich zachowanie? Co odczuwają? Faza wstẹpna nazywana jest pruez niektérych fazq obcoscit ${ }^{\text {th }}$, gdyż na począlku poszczególne osoby są sobie nuwzajem calkowicie lub w jakiejś mierze obce, jak też sytuacja bycia w (nowej) grupje względnic wchodzenia w (nowa) grupę jest dla nich obca. Towaryssza im cickawosc i wytezzona uwaga z jednej strony oraz napięcie, niepewnośt, lęk, poczucie bycia wydanym na pastwę innych z drugiej strony. Sytuacja jest calkowicie otwarta: niczego się nic wic prócz tego, że chce się należec do tej grupy. Jednostka nie wie, jakie są lub będą inne jednostki, czy ja zaakceptują, czego od niej oczekują i czy znajdzie w grupie swoje miejsce. Obie podstawowe ludzkie potzzeby: uznania i bezpieczeństwa, na początku albo w ogóte nie sa spełnione, albo jedynie fragmentarycznie. Taki wewnęrzny stan, twierdzi I. Klein, wywotuje dwie sprzeczne ze sobq - zwykle tatwo zauwazalne - tendencje w zachowaniach: wychodzenie sobie napreciw i uciekanie od siebie nawzajem. Ludzie restujq sie wzajemnie, obsenwtjq, probuja znalezé pienwse punkly oparcia, zbliżajq̨ sie choćby do jednego z uczesthików. Zaczynaja ste onienrować, co kro mylíl i komu mozna ufać. Wazne jest, by mieć kogos, do kogo mozina by się odniét, najlepiej, gdy jest to lider grtup; on preciè musi wiedziec co dalej, on zna reguly gr ${ }^{\prime 7}$. Na skutek jakicgoś zachowania, jakiejś sytuacji lub wręcz prcypadku mogą już w tej fazie powstać — uswiadomione lub nieušiadomione, wyrażone Iub nic wyrazone - pierwsze reguly i normy grupy. Np. grupa nie zgadza się z jakąs propozycją lidera. Opanowanie, z jakirn to przyjmuje i jego otwarcie na propozycje grupy prowadzi do powstania nie wypowiedzianej normy: tutaj wolno knykkować. Tworzenie takich regul gry wynika z potrzeby bezpieczéstwa; ustalcnie kilku takich pewnych punktów zaczepienia lagodzi lq̧ki uczestnikơw. W pienwszej fazie dokonuje się też przyjmowanie i przypisywanie ról. W każdej grupic sq̨ tacy czlonkowie, którzy chętnie się wypowiadaja - niekiedy za wszelka cenę i nickompetentnie - i tacy, którzy wolą się przysluchiwać i przypattywac. Tym pierwszyn przypisuje się często rolę rzeczników grapy. To na nich patrzy wyczekująco reszla grupy, gdy trzeba podjąc jakąs decyzję. Inni ledwo lub wcale nje są zauważani; tym przypisuje się roię milczków. W tym procesie szukania swojego miejsca w gnupie (niekiedy jest on zaciektą walką) mogạ pojawic się tendencje do tworzenia podgrup w sensje frakcji i koalicjil"

Na koniec wyliczmy najważniejsze czynniki, kıóre sprawiają, że jednostka mówi lak grupie i do niej przystępuje, i które sa jednoczérnie bardzo istotne dla egzystencji grupy' Zanim ktoś odpowie na wezwanic do tworzenia wspólnoty, odkrywa w niej siłc̨, która może go wyzwolić a 1ego wszystkiego, co go izoluje i atrudnia jego rozwój. To właśnie potrzeba $i$ koniecznof́c wyzwolenia tworzy silę prayciągania i integracji grupy. To ona pozwala jednostce przezwyciężć egocentryzm i daje możliwošc uгzeczywistnienia najgłębszych pragnieŕ. Nie będzie to jetnak mozliwe, jeśli jednosika nie dostrzeże jednocześnie koniecznotci socjalizacji. Alc też cala grupa ma za zadanie wnieśc

It 1. Kle in: Gruppenleiten ohne Anght. Ein Handbuch fïr Grppenlerter Mümchen 1991 \&. $27-32$.

II Tamíc, s. 28 .

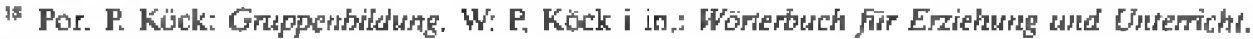
Donaturoth 1975 \$ 161.

${ }^{19}$ Por. J. B. Cappellato $\mathrm{i}$ in $\mathrm{r}_{\mathrm{s}} \mathrm{dz}, \mathrm{cyt} \mathrm{t}_{+}$s. 194-195. 
mieco światla w osobiste dzieje jednostki, w to wszystko, co wnosi ona do wspólnoty, w jej spoleczne zachowania, jej sukcesy i porażki, pozytywne doświadczenia i frustracje w spotkaniu z innymi, psychologiczne blokady i urazy, i pornóc jej pokonać lub ograniczyé do mínimum to co negatywne. Każdy, kto szuka w jakiejśs grupie wyzwolenia, sumorealizaçi i potwicrdzeria, a więc zbawczych doswiadczeń, ma nadzieję na powodzenie. Stanie się tak, jeśli grupa da mu możliwośc wyraženia siecbie i osiagrniçcia czegok. To prawdopodobieństwo sukcesu zaklada jednak osobiste zaangazowanie. Natomiast zadaniem grupy jest tu znalezienie właściwego stosunku między koniecznym zaangażowaniem a spodziewanymi rezultatami.

\section{Fazo orientacji — stosunkj międzyludzkje}

Stosunki miçdzyludzkic mają dwie istotne cechy: są wiclowarstwowe i żywe. Pod zewnętrzną warstwą wyglįdu, osobistego uroku, atrakcyjnosci, uzcolnich́, dobrcgo zachowania, które są zwykle decydujące dla nawiazzania stosunków, kryja się nierzadko poczucie winy, niespelnione nadzicje, pragnienie bezpieczeństwa, egoizm, ambicje, brak samoakceptacji, agresja itd. Relacje międzyludzkie są poza tym czymś, co może się przez lata utrzymać w niezmienionej postaci. Grupa musi więc wziąc pod uwage calego cztowieka, z cala jego rzeczywistoscig. W przeciwnym razie tak istone dla nicj wzajemne odniesienia pozostaną powierzchowne. Grupa zaczyna wzrastać, tzn. stawac się wspólnotą, nie wtedy, gdy oferuje đostateczną ilośc możliwosci wspólnego działania, lecz wówczas, gdy zwraca się w stronę potrzeb jednostki, jej przeróznych warstw. Wspólne dzialania niewątpliwie proyczyiaja się do rozwoju grupy, do powstania wiclorakich powiązá między poszczególnymi czlonkami, ale zbyt duzy nacisk tha akcje może ją zniszczyć.

Stosunki miçdzyludzkie wysuwaja się w tej fazje na pierwszy plan. Ich rozwój leży w interesie każdego cztonka grupy. Każda jednostka potrebuje dobrych, przyjacielskich stosunków, by mogla pozostać w grupie. To zaś oznacza znajdować uznanie i uznaniem darzyć, miec jako takie poczucie bezpieczeñstwa j je clawać, być w jakimś sensie ważnyrn dla innych, miee jakiś wpływ ga syluację w grupie, a więc i na innych. Szukanie czy walka o uzthawane przez resztę miejsce w grupie jest w tej fazic stale aktualnym tematem. W sumie chodzi w niej o wyklarowanie sic relacji między czlonkani grupy, o szukanie orientacji, o znalczienie odpowiedzi na takie pytania jak: Czy moge i czy chce tutaj zostac? Cy zrajduje tutaj to, czego szukam i potrebule?

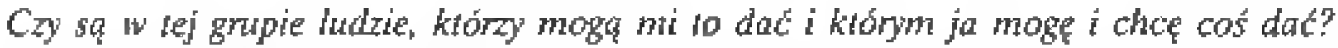
Wszystko to zas stanowi proces pelen napięć i burz emocjonalmych, wzlotów i upadków.

Szczególnie w grupach, które nic mają na początku ustalonego celu, proces ten dokoruje się najpierw na plaszczyźnic towarzyskicj. Wspólne muzykowanic, gotowanie, pieczenie, zabawa jest często poczz tkiem tego procesu i powodem, ale też i glównym powodem, dla którego ludzie spotykają się ze sobą od czasu do czasu. Stopnjowo jednak dochodzi między nimi do rozmów, dyskusji nâ tenat spraw zycia codzienrego, polityki, problemów spolecznych i teligii. Jesli jednak zaangazowanic emocjoralne uczestników jest pryy tym niezwykle duze, a temat rozmowy jawi się raczej jako drugorzerdny, to chodzi tu bardziej o wzajenne relacjc niz o przedmiot dyskusji. 
$\mathrm{Z}$ czasem - po fazie ostrożncgo testowania - zaczyna się mówić też o osobistych problemach - w nadziei, że grupa pomoże je rozwiązać. Ten etap nazywany jest czasami faza otrzymywania ${ }^{20}$. Jednostka otrzymuje tu oparcie i potwierdzenic ze strony grupy. Branie zakłada jednak dawanie: nie tylko pozwalamy uczestniczyć innym w naszym życiu, lecz także uczestniczymy w życiu innych. Wymaga to atmosfery zaufania, otwartości, a także dużej koncentracji w sensie wewnętrznej czujności. Te zaś są rezultatem długotrwałego procesu uczenia siç, w którym muszą wziąć udzial wszyscy czlonkowie grupy. Nie dokona się to jednak u nich wszystkich jednocześnie. Najważ. niejsze jest, aby wszyscy byli stale gotowi do uczestniczenia w tym procesie. Członkowie grupy powinni okazywać sobie wzajemnic bliskość i troskliwość, przyjmując przy tym postawę podobną do tej, jaką przyjmują rodzice względem swoich dzieci: będą nieraz dla siebic jak matka, która - jak mówi E. Fromm - jest dla dziecka ciepłem²1. Stworzone przez to poczucie bezpicczeństwa pomaga uczestnikom w akceptacji i artykulacji wlasnych uczuć i potrzeb. Konieczne jest też, aby zdjęte zostaly maski, za którymi niektórzy się ukrywają. Obowiązuje zasada autentyczności, kongruencji, zgodności tego, co człowiek myśli i odczuwa, z tym, co okazuje na zewnątrz. Im więcej takich wzajemnych odniesień, tym mocniejsze więzi lączące poszczególnych czlonków grupy.

Nie ma wzrostu bez irudnosci. W procesie rozwoju grupy ważną rolę odgrywają wyzwanie i konfrontacja. Mają one pomóc jednostce odkryć w sobie ukryte, zablokowane i niewykorzystane możliwości. W żadnym wypadku nie wolno ich wykorzystywać do ośmieszenia lub poniżenia kogokolwick. Grupa powinna więc uczyć się kreatywnego podcjścia do negatywnych odczuć, negatywncj krytyki i sytuacji konflikıwych, kıóre $z$ dużą prawdopodobnością będą się w tcj fazie pojawiać: ktoś czuje się w czyms pominięty, na kimś skupia stale się czyjaś zlość, ktoś zawsze na coś narzeka, ktoś notorycznie się spóźnia, ktoś miga się od pracy itp. Wielce przydatna jest znajomość regul feedbacku'22. W grupie, do kıórej należalem - opowiada W. Müller (chodzi o grupę spotkaniową) - uptynęlo wiele czasu, zanim byliśmy w stanie uzewnętrznić nasz gniew. Byliśmy co prawda zdolni do mówienia o gniewie, o naszym gniewie względem rodziców, wspótmalizonka, Kościoła itd., w gnupie śmialiśmy się i nawet płakaliśmy; ale prawdziwego gniewu nikt nigdy nie pokazal. Dopiero podczas ostalniego spolkania - znowu rozmawialiśmy na temat Josefa, kióny stat w centrum prawie wszystkich posicdzeń - Annelle powiedziała nagle: „Mam już tego dosyć! Czy nie widzicie, ze cały czas skupialismy się na Josefie rylko dlatego, by uciec od konfrontacji z samym sobn? ${ }^{\alpha}$. Była bardzo wzburzona. Potrzebowala tak wiele czasu, by móc uzewnętrznic swoja irytację spowodowang zachowaniem grupy. Być może do konica Annette nie mogla odzyskać zaufania do naszej gnıpy $i$ czuć sį̨ $w$ niej akceptowang, gdy wyrażala swoje niezadowolenie z zachowania się innych uczestników ${ }^{23}$.

Tamie, s. 197.

"E. Fromm: Dic Kunst des Liebens. Frankfurt a. M. 1978 s. 61.

2 Zob. E. R. Schmidt i in.: Aufhören und Anfangen. Wechselfalle im Allug einer Gemeinde. Gelshausen 1983 s. 62n; por. O. Belz, dz. cyt., s. 31; J. Gricsbeck: Kleines Gruppenteilerbuch. München 1988 s. 26-32; M. Kaszowiski: Poradnik animatora. Podstawy chrzescijariskicj formacji. Katowice 1988 s. 21.

${ }^{2}$ W. Müller, dz. cyı., 72-73. 
W odniesieniu do takich doświadczeń — a w fazie akcji w sposób szczególny czlonkowie grupy powinni uświadomić sobie, żc emocje odgrywają zasadniczą rolę w tworzeniu siç relacji międzyludzkich. Uczucia rodzą pierwsze zawiązki wspólnoty; tkwi w nich siła łącząca ludzi, którzy dotychczas byli sobie obcy. O tym, że odnosi się to także do uczuć negatywnych, świadczy wypowiedź M. Dammann: Ja osobiscie cieszę się, że mam grupę, w kıórej dzielenie się rezygnacja dodaje mi odwagi... ${ }^{24}$ Opisane przcz nią doświadczenia w ekumenicznym zaangażowaniu się na rzecz pokoju na świecic to nie tylko sukcesy; przemieszane są one z okresami zwątpienia w sens ich pracy. Mimo to grupa nie przestala wzrastać jako wspólnota, wypełniać swoje zadania, a przede wszystkim podtrzymywać nadzieję, że do przemocy nie należy ostatnic slowo.

$\mathrm{Na}$ gruncie takich czy podobnych procesów rozwija się życie grupy, życie w grupie i dla grupy. Wcześniej czy później doprowadzi ono wszystkich jej czlonków do głçbokich pytań egzystencjalnych. Takie istotne wartości jak sens życia i śmierci, religia, etos, miłość, praca, pokój itp. zaczynają stopniowo zyskiwać pienwszeństwo przed indywidualnymi interesami. Np. dla grupy teatralnej zaczyna być nagle mniej ważne to, że chce ona wystawić jaką̧s szlukę̨, lecz przede wszystkim, co poprzez tę sztukę przekaże ona widzom. Najpierw jednak ona sama będzie musiala ustosunkować się do treści przygotowywancgo przedstawienia, jeśli chce wiedzieć, jakie jest orędzie, które należy przekazać widzom. Dobrze jest, gdy grupa stosunkowo szybko odkryje, żc to wspólne poszukiwanie orędzia stuży nie tylko ich potencjalnym sluchaczom, lecz także ją samą rozwija i pozwala jej wniknąc w głębsze pokłady ludzkiej egzystencji ${ }^{25}$.

W każdej grupie chrześcijańskicj powinno dojśc do odkrycia, że owe wielkie wartości, nadające życiu sens, są właśnie tymi cwangelicznymi wartościami, które glosił Jezus. W tcj fazie, która nazywana jest też faza gloszenia Ewangelii ${ }^{26}$, członkowie grupy muszą spojrzeć na swoje życie w świetle Ewangelii. Skoro tylko zaczną na serio zajmować się istotnymi problemami życiowymi, spostrzega, że ich sposoby patrzenia na rzcczywistość. poglądy i oczekiwania są bardzo różne, że trudno zrozumicć drugiego czlowieka, że każda rozmowa stawia przed nimi zbyt wiele wyzwań, że czują się przeciążeni, gdyż jest po prostu za dużo rzeczy, kıóre należało by zmienić. Uświadomienie sobie tych problemów prowadzi do postawienia szeregu ważnych pytań: Dlaczego 'worzymy gnupę? Co nas połqczyło? Czego oczekiwalismy? Co dalej?, i zwykle wywoluje kryzys, określany mianem knzysu sıosunków międzyludzkich ${ }^{27}$. Bierze się on z napięcia pomiędzy tym nowym odkryciem a obstawaniem przy starych oczekiwaniach i dotychczasowej formie bycia razem, pomiędzy pragnieniem pozostania w grupie a wolą jej opuszczenia. $\mathrm{Ci}$, którzy nie chcą udać się na đrogę wspólnych poszukiwań sensu własnego życia i życia grupy, i woleliby ograniczyć się do płaszczyzny towarzyskiej,

¿ E. Dammann: Okumenische Friedensarbeit in Haltem. W: Wie wir Gemeinde wurden. Lemerfahningen und Emeuenungsprozesse in der Volkskirche. Red. N. Mette. Mainz 1982 s. 167.

${ }^{23}$ Więcej na ten temat: N. Derksen: Gemeindeaufbau und Glaubenskommunikation im Bibliodrama. "Lebendige Seelsorge" nr 3 (1995) s. 120-126; W. Wilk: Teair a przepowiadanie. "Kronika Diecezji Sandomicrsko-radomskicj" nr 7-8 (1984) s. 177-185.

26 J. B. Cappellaro $\mathrm{i}$ in., dz. cyl., s. 196.

"Tamże, s. 197. 
opuszczają grupę. Taki kryzys występuje w każdej grupie w różnym stopniu — równicż w grupach, które mają od samego początku wyraźnie ustalone i sprecyzowane cele. Nierozumienie tych celów lub błędne ich pojmowanie (często nicuświadomione) może nie tylko zakłócić ich realizację, lecz także hamować wlaściwy rozwój stosunków międzyludzkich w tych grupach. Ministranci, którzy traktują swoją grupę ministrancką jedynie jako klub pingpongowy, a nic jako wspólnotę, w której możc rozwijać się ich życie $z$ wiary, są przyczyną napięć. Nierzadko rodzice chcą, by ich dziecko należało do jakiejś kościelnej grupy. Oni sami jednak nie mają wiele wspólnego $z$ wiarą i Kościołem lub wiążą z kościelnymi grupami zupełnie inne oczckiwania niż Kościół i same grupy. Jednakże przekonanie, że ci ludzie i ich dzieci nie powinni być dopuszczani do grup kościelnych, jest falszywe. Szczera rozmowa, osobiste swiadectwo, prawdziwe glębokic spotkanie z nimi może zmienić ich nastawienie.

Omawiany tu kryzys może trwać dluższy czas i jest z pewnością dla członków grupy bardzo bolesny. Jego pokonanic zależy od stopnia gotowości do przyjęcia i wykorzystania wszystkich pojawiających się szans na dojrzewanie własnej osobowości i życia duchowego oraz gotowości do wspólnego uczenia siç życia Ewangelią. Ważne jest, aby Ewangelia byla w grupie rzeczywiscie gloszona. Tylko w ten sposób zostaną stworzone okazje do refleksji i rozmowy na temat przemiany i do otwarcia siç na nią. Bardziej niż zwykle członkowie grupy potrzebują w tym okresie pomocy innych zwlaszcza lidera grupy, który w tej fazie jest jeszcze autorytetcm, ojcem, który pobudza, zwraca uwagę, a niekiedy przynagla. Z pewnością słuszne jest twierdzenie, że grupom, które mają swojego kierownika, powodzi się w okresie kryzysu znacznie lepiej niż grupom, które go nie posiadają. Nie znaczy to jednak, że te ostatnic nie są w stanie samodzielnie wyjść z kryzysu. Co prawda zdani są bardziej na wsparcic i impulsy $z$ własnych szeregów, ale właśnie to pokazujc, jak ważne są te czynniki i że inne grupy powinny taką drogę uwzględnič, zanim w swojej bezradności złożą całą swoją nadzieję w liderze. Każda grupa znajdują̧ca się w obrębie, kontekście chrześcijańskiej wspólnoty, parafii, ma prawo też oczekiwać od niej pomocy i tę pomoc otrzymać. Parafia jest bowiem micjscem, w którym człowiek wrasta w wiarę chrześcijańską, gdzie można doświadczać zdobywczej mocy i przyciqgającego światla Jezusowego orędzia²

Dotychczasowy opis przcbiegu procesu grupowego można zilustrować następującym przykładem z życia: W grupie dla malżeństw (szesć par w średnim wieku), która początkowo miala charakter czysto towarzyski (za namową proboszcza spotykali się dosć regularnie, by porozmawiać, spędzić miły wieczór, wybrać się wspólnic na wycieczkę albo pomagać przy festynie parafialnym), dochodziło coraz częściej do poważnych rozmów na temat relacji małżeńskich. Wywołała je częsta nieobecność jedncj z par. Po nawiązaniu kontaktu dowiedziano się, że małżeństwo to rozpada się. Wkrótce dotarla do grupy wiadomośc, że owi małżonkowie są już po rozwodzie. Na gruncie tych wydarzeń zrodzilo się przekonanic, że rozmowa w grupie na temat problemów małżeńskich, wymiana poglądów i doświadczeń oraz wspólne poszukiwanic rozwiązań będzie dla wszystkich uczestników bardzo pomocne i ubogacające. Nie-

28 O. Saier: Fastenhirtenbrief 1989. „Konradsblatt” nr 8 (1989); por. W. Kasper: Theologie und Kirche. Mainz 1987, szczeg. s. 277n. 
które osoby odniosly się z entuzjazmem do tego pomysłu i przyznały nawet, że i one przeżywają niekicdy kryzysy. Inni podeszli do tego dość sceptycznie, ale w końcu większość poparla propozycję. Tylko jedna para oznajmiła, że nie widzi potrzeby omawiania swoich problemów malżeńskich na fonım publicznym i wkrótce opuściła grupç. Pozostali czlonkowie mieli na początku trudności z opowiadaniem o swoich osobistych sprawach. Spróbowano więc innej drogi: zaczęto dyskutować bardziej ogólnic, np. na temat nierozerwalności malżeństwa czy ludzi rozwiedzionych i żyjących w związkach niesakramentalnych. Dyskusje ujawnity dość duże różnice poglądów; doszło nawet do sytuacji konfliktowych, w których jedni poczuli się zaatakowani i oskarżeni przez drugich i o malo co nie opuścili grupy. Takic napięcia utrzymywały się przez dłuższy czas i grupie zagrażal rozpad, aż zdecydowano się szukać pomocy u innych. Zaproszono malżeństwo katechctów, którzy pracowali także w parafialncj poradni rodzinnej i prowadzili niektóre spotkania w ramach kursów przedmałżeńskich. Po kilku wicczorach z nimi stalo się jasne, że tylko wtedy będą mogli dalej egzystować jako grupa, gdy wszyscy czlonkowic zrozumieją, żc omawiane przez nich problemy ich także dotyczą lub mogą dotyczyć i że grupa jest dla nich jedyną w swoim rodzaju okazją do refleksji nad życiem małżcńskim i umocnicnia więzi między małżonkami.

Opisana tu faza jest w gruncie rzeczy pelnym burz i napon, wymagającym wsparcia procesem szukania orientacji. Niektórzy nazywają ją także fazq znajdowania miejsca ${ }^{2 y}$. Jeśli grupa zakończy te poszukiwania sukcesem, wkracza w następną fazę swojego życia, fazę wzrostu i dojrzewania nowo odkrytego i przyjętego ideału.

\section{Faza integracji - wzrost $\mathrm{i}$ dojrzewanic ideału}

Faza ta zaczyna siç konicczną na tym etapie refleksją, czymś w rodzaju przystaniçcia i systematycznej retrospekcji, przyjrzenia siç sobie samemu, swoim emocjom, wzlotom i upadkom, kryzysom, indywidualnym i wspólnotowym doświadczeniom, odkryciom i sukcesom w poprzednim stadium. Wszystko to zostaje zinterpretowane i uporządkowane. Każdy wic teraz z grubsza, czego muże spodziewać się po sobie $i$ innych czlonkach grupy, jakie mocne i słabe strony ma on, a jakie inni. Każdy wic, gdzic jest jego miejsce w grupie. Każdy stosuje się też do ustalonych przez grupę regul postępowania. Wszyscy mają świadomość przynależności do grupy, poczucie bycia grupą, wyrażające się już w samym słowie my, często używanym przez członków grupy i w specyficznych dla grupy terminach, wyrażeniach, skrótach itp. (język grupowy), symbolach, a niekiedy nawet w jednolitych strojach. Po fazie niepokoju wszyscy czują się teraz pewni i bezpieczni: każdy może liczyć na każdego. Grupa zna swój cel i ma wyobrażenie ideału, do którego dąży. Wlaśnie w tym stadium ma ona najwięcej sily do wspólnych działań. Pojedynczy czlonek określa swoją tożsamość przede wszystkim poprzcz przynależność do grupy, dlatego bardzo niechętnie $z$ nią się rozstaje.

Zadanie lidera polega tu w pierwszym rzędzie na pobudzaniu grupy do egzystencjalnego, a nic tylko pojęciowcgo odkrywania idealu, integrowania jej wokól tego

31. Klein, dz. cyt., s. 32-38. 
ideału i prowadzenia jej do samookreślenia. Jest on koordynatorem, opickınem i towarzyszem, który nie dysponuje i nie powinien dysponować gotowymi odpowiedziami, lecz przyczynia siç do tego, że te odpowiedzi zostają znalezione przez grupę i każdego jej czlonka.

Wiele w tcj fazic odbierane jest przcz członków grupy jako zadowalające i dobre. Ale rozwój grupy moźe też pójść niewlasciwym kierunku. Ponicważ woprzednjej fazic było tyle niepewrości, czlonkowie grupy mają w obecnej fazie skłonnošc do przedwczesnej i przesadncj zażyłłci. Tendencja do unikania wszelkich konfliktów i zaklb́ceń każe akcentowac niemalże balwocl walczo owo my i jednomyślnośc oraz ignorow tóc odmiennošc i indywidualnošc poszczególnych członków. Jeśli urięc któryś z nich przekroczy jakąś notmę grupową, to spotyka się z ostrą krytyką ze strony teszty grupy. Z obawy przed utrata zdobytej z lak wielkim truder jednošci grupa nie dopuszcza do sjebic nic nowego i zaczyna odcinac się od otaczającego ją świala. $\mathrm{Na}$

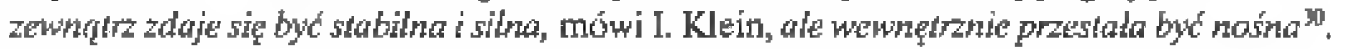
$\mathrm{Z}$ práktyki wiadomo, ze wiele grup utkwito w tym stanie.

W fazie integracji grupa dociera do punktu, w ktốrym już wie, czego choc, ule jeszcze nie wie, jak to osiagnać. Jej członkowie nic znaleźli jeszcze sposobu na to, by nic tylko byé razem, ale i wspólnie dzjatać oraz cos osiagną́. To bardzo trudne zadanje, gdyż znalezienic takjej wspólnej drogi wymaga z jednej strony od każdego czlonka ograniczenia swojej indywiduatnosci i prajejecia odpowicdzialnośch, a z drugiej strony zharmonizowania interesow grupy $\mathrm{z}$ indywidualnymi interesami jej poszczególnych członków. Josli się to nie uda, to pojawia się nowy kryzys, bardzo bolesny, bo więzi sa tu znacznic silniejsze i glębsze niż w poprzedniej fazic. Ponicważ kryzys ten jest rezultatem zróżnicowanych rytmốw wzrastania poszczcgólnych członkơw, może doprowadzie do rozlamu w grupic. Wowczas trzeba będzie dopuścic dwa róże stoprie rozwojud lub pogodzic się z powstanien dwóch odrębrych grup.

Grupa może jednak rozwijać się pozytywrie, gdy otwarcie mówi siç w aiej o trudnościach, kiedy nie zabrania, a dopuszcza ona odmienne poglądy, odczucia, potrzeby i nawet pewne napięcia, gdyz nie muszą byc one od razu interpretowanc jako atak lub kontustacja; kiedy upragniona i rodząca się zażylosel traktowaja jest przez każdego członka jako moźliwość pokazania siebie jako indyniduum, odważenia się na coś wiçccj, wriesienia czegós osobistego do procesu grupowego.

Takim i podobnym procesom podlega także grupa koścjelna. Jej integracja moźe dokcnywać się na drodze wspólnej refleksji nad wiarą chrześcijańską, nad chrześcijańskim ideałern życia. Cztonkowie grupy próbuja spojrzé na swoje doswiałczenia i na sytuacje grupy w swietle Ewangelii. Podczas czytania Pisma słwiętego grupa może odkryc siebie na nowo i stopniowo odnajdowac własny styl zycia. $Z$ czasem zacznie się coraz bardziej identyfikować z jednym i tym samym idealem. Pomoze jej to $w$ dostrzeżeniu i skonkretyzowantu whaściwego jej celu. Swiadomość prawa do istsienia budzi w riej potrzebe urzecrywistnienia tego celu zarówno we wzajemnych telacjach,

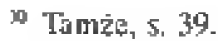

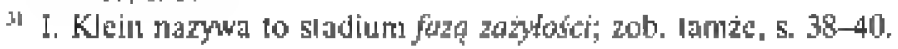


jak i w konkretnym działaniu. Ten etap dojrzewania można porównać z katechumenatem wosciele pierwotnym, z jego skrutyniami, ośtwieceniami i wspolnym zaangażowaniem na drodze do przyjęcia chrztu ${ }^{32}$. W naszej przykładowej grupie dlia par malżeńskich wygladałoby to tak: Podczas spotkań członkowie grupy spostrzegają, że otwarte mówienie o sukcesach i niepowodzeniach moźe mieć charakter wychowawczy. Nieraz bowiem jakiejs parze wydawało się, że problemy o których opowiadają, dotycza tylko ich samych, i poten okazywało się̧, że inni doskonale je znają, gdyz tcż je przezyuali bądź przeżywają. Ten poxytywny feedback i wsparcie ze strony innych cztorkó grupy eliminuje poczucie izolacji, ułatwia wzajemną komur ikację i dokladriejsze, uczciwsze podejscie do problemów. Im szczerzej rozmawiaja względnie potrafią rozmawiac zc sobł, tym tresciwsze są poszczególne wypowiedzi, tym wyraźniejsze jest dośwladczenie bliskuści i wspolnoty. W ten sposób grupa staje się coraz bardziej micjscem, w ktorym jej czlonkowie pokazują sobie nawzajem, jakie znaczenie ma dla ich małżcnstwa osobiste odniesienic do Boga i Kosciola i jaki wlyw na ich odriesienie do Boga mają ich relacje małżenskie. Dla niektórych z uczestników może być trudne mówić tak otwarcie o duchowyn wymiarze swojego małżeństwa. Inni ratomiast potraktuja to jako cos w rodzaju ozywienia sakramentu matzenstwa. U niek tórych doprowadzi to do duchowego pogłę̧bienia i ubogacenja relacji małżenskich i ich codzicnności. Małżonkowie odkrywaja w ten sposób dynamikę dialogu, do której tależy pelnia i niedostatek, jednośc i różnorodnobc, zgoda i spó $r^{33}$, i która nie tylko nadaje nowy wymiar ich matżeńskiej wspólnocie, lecz także integruje całą grupę i ponaga jej stawac się intensynwną wşólnotą.

\section{Faza nowej orientacji - intensywna wspóhnota}

Grupa przechodzi do fazy nowej orientacji i intensywnej wspólnoty, jeśli uda się jej pokonać trud nósci poprzedniej fazy i znaléś swój ideat oraz sposób jego realizacji. Musi ona przy tym znaležć złoty środek między akceptacja odrębności i różnorodności jej poszczególnych czlonków z jednej strony a dążeniem grupy jako całości do harmonii i jedtności z drugiej strony. Grupa uznaje więc istnienie różnic pomiędzy jej colonkami i próbuje otwarcie żyé z tymi różnicami ${ }^{3 / 4}$. Każdy więc może być takin, jakim jest. Kazdy ma też prawo się zmicnić. Każdy może wyrażać swoje zdanie, nje bojąc się odrzucenia i izolacji. Osobiste zapatrywania, różnice i zmiany nie wywolują konfliktów, nic s耳 srodkami walki, lecz traktowane sa jako wezwanie do owocnej dyskusij w atmosferze wzajemnego szacunku, jako szansa na sukces calcj grupy. Konfliky to nie wolizjew we wrpótyciu, lecz nomalne oznaki navzej rónorodinoșci. Relacje sa zawsze podatne na zanienia, stale musimy nad nimi otwarcie pracolvac ${ }^{33}$. Grupa już nie zamyka się na otaczajacy ją swiat, gdyz wszystko co nowe nie jest przez nią traktowane jako zagrożenie dla wypracowanej jednosci, lecz jako cenny bodziec do owocnej kontrontaci.

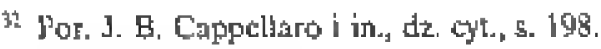

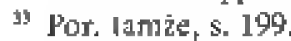

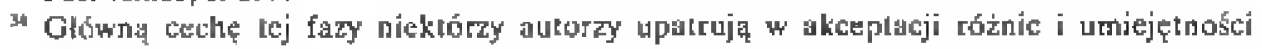

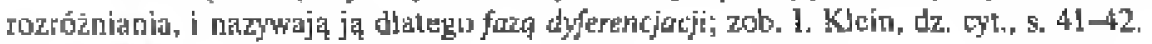

피 Tanze, s, 41 . 
Jednakże intensywha wspólnota wymaga jednoczcśnte od każdego z członków umierania dla grupy, by mó ją calkowicie przyjąe i ponwolic jej zyc i dzialac. Kazdy jest w stanie zanegowac swoje ja, hie stajqc sie przez to mniej sobq ${ }^{36}$. Każdy czlonek grupy ubogaca swoją indywidualnoscią, swoinhi uzdoInieniami, swoją osobą życie i dzialalnose grupy, a przez to ubogaca samego siebie. Nie działa on jednak jako jednostka przy poparciu innych, lecz jako jednostka z dokladnie okreșlonym zdaniem w imicniu wspólnoty. Nazywa się to twórczq kooperacja samodzielnych pojedynczych ${ }^{37}$. Swiadomosé indywidualnostei i swiadomosé uspotecznienia, biskosé i dystans, ja i my saz tutaj w tównowadze. Heteronomia j autonomia stają się na tym etapie homononią". Bardzo wyraźnie widać tu, że czlowiek jest indyuiduum i ze jednocześnte żyje w spolecznych relacjach, że jest odpowiedzialny za siebie i za innych. Czlonkowfe grupy spostrzegają też ze milośc bliźniego nie musi pociągac za sobą całkowitego zaparcia się sicbie. Jesli grupa i każdy jej członck z osobna osiągną taką waśnic świadomośc i takie rozumienie grupy, to będzie to dla niej i jej czlonków rzeczywiście nowa orientacj:

Osiągnięcie i zachowanie tej nowej orientacji wymaga ciąglego wysilku. Grupa poddaje się więc nie ustannerru, dynamicznemu procesowi dojrzewania, który wyzwala wiele energii, tworczej mocy i inicjatyw. Wczesniej jej dzialania skierowane byly bardziej na zewnątrz - teraz zaś batdziej do wewnątrz, by zachowac jednośc i nic zapomnieć o rozwoju poszczególnych osób. Grupa nastawia się wiçc teraz na swój specyficzny cel. Jej dzjalania są planowane, zadanie rozdzielane, a dla ich wypetnicIria tworzy się caęsto podgrupy. Dynamikę tcgo procesu można porównad a kolem kręcacym się wokól osi: Osiq sq cele, do któnch zmierza dzialalhośc grupy. Kolem jest proces zhamonizowanych ze soba akcji, szkolenia i rewizji

$A k c j a$ jest istotnym tyyznacznikiem grupy chrześcijańskicj. Poprzez autentyczne zangazowanie staje się ona swiadkiem, który przekazuje jakieś orędzie. Zaangažwanie może być autentyczne jedynie wtedy, gdy poprzedza je autentyczna decyzja grupy o zrealizowaniu jakicgoś konkretnego planu. Decyzja grupy zaś wymaga opracowania programu, đo którcgo naleźą znajomość otoczenia, jego potrzeb i pragnień, możliwe odpowiedzi ze strony grupy, a przede wszystkim akceptowany przez ws zystkith cel. Program sklada się z pojedynczych, zestrojonych ze soba i wzajemnie się uzupełniajacych zadan, za które kaźdy członek grupy jest wspołodpowiedzialny. Nie może byc mowy o autentycznym zaangażowaniu grupy, jeśli jest ono jej narzucone z zewnattrz, odgónie. Podobnie jest, gdy planowanie ma zbyt teoretyczny charakter.

Akcja bez szkolenia staje się zwykłym aktywizmem. Stałte, zorientowane na cele grupy i osobiste doswiadczenia szkolenie jest konieczne zarówno dla każdego pojcdynczego crlonka, jak i calej grupy. Jego celem jest uzdolnienic każdego czlonka grupy do oddziaływania na cala grupe i przejmowania za tiia i w niej odpowiedzialnosci. Szkolenie nusi być pojmowane zawsze jako odpowiedź na koniecznośc akcji; musi

16. I. B. Cappellaro i în., dz, cyt., s. 199,

${ }^{3}$ D. Stollberg, dz tyt . s. B2.

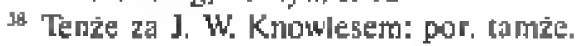

3. b. Cuppellato i int. de cyn, s. 200 . 
ono prowadzić do zaangażowania, gdyż w przeciwnym razic pozostanie bezowocnc, a dla czlonków grupy będzie po prostu deprymujące.

Akcja i szkolenie mogą być poddane refleksji i kontroli w rewizji. Chodzi tu o wspólnie przeprowadzany sprawdzian celów, działań, osobistego zaangażowania i wıajemnych relacji w grupie. Rewizja jest pierwszorzędnym środkiem wychowawczym w akcji. Dzięki szkoleniu rewizja nie jest powierzchowna. Grupa może ustalić stale terminy, w których regularnie będzie dokonywała rewizji, aby uniknąc sytuacji, w której jedni drugi wpędzają w kryzysy albo swoje kryzysy projektują na innych. Ponicważ kierowanie grupą jest w tej fazie wspólnym, opartym na zasadnie równouprawnicnia zadaniem względnie funkcją grupy, lider staje się bardziej częścią grupy. Jeśli jest to konieczne, może ją do czegoś zachęcać, wspierać ją w czymś lub przypominać jej o wspólnie sformulowanych celach.

Właśnic to stadium jest docelową fazą w życiu grupy. To przede wszystkim ona umożliwia pojedynczym czlonkom optymalne wykorzystanie pozytywnych potencjatów grupy i prostuje przez to drogę do ich osobistego rozwoju i samorealizacji.

\section{Faza rozstania - grupa w agonii}

Niestety, także i w fazie wewnętrznej (relacje) i zewnętrznej (dzialania) dojrzalości grupy może zrodzić się kryzys. Brzmi to zapewne dziwnic, ale wlaśnie sukces może doprowadzić grupç do fazy rozstania. Mogą pojawić się różne nowe cele inne niż te, które towarzyszyły tworzeniu się grupy. Grupa może też odkryć nowe pola dzialania albo konieczność ich rozszerzenia. Te czynniki $-w$ powiązaniu $z$ innymi, jak np. przeniesienie lub przejście lidera do innych zadań - mogą zmienić ogólną sytuację grupy. Musi ona wtedy zdecydować, czy podzicli się na podgrupy $z$ własnymi zakresami działania, czy też zgodzi się na powstanie nowych grup. Taka decyzja jest co prawda bolcsna dla czlonków grupy, ale teź i owocna. Obraz ziarna pszenicznego, kı́ore obumiera w ziemi, by wydać obfity plon (por. J 12,24), najlepiej odzwicrcicdla tę sytuację. Ta konieczność umierania zostaje przez grupę przyjęta mimo bólu — na plaszczyźnie jej dojrzałości. Czlonkowic grupy wiedzą, że dzisiaj rozstanie znaczy dla nich coś innego niż wcześniej. To czas owocowania $i$ - by pozostać pray porúwnaniu z chrześcijańskim wtajemniczeniem (proces przygotowania) - czas, w kiónym realizowane sq przyrzeczenia chrzcielne, a Eucharystia zyskuje swoje petne znaczenie, izn. czas intensywnej wspólnoty i skludania innym daru ze swojego życia ${ }^{40}$. Kto doświadczył prawdziwej wspólnoty, będzie korzystal ze swoich doświadczeń, gdy wejdzie w inne zyciowe wspólnoty. Wiclu takich ludzi - pokazuje to praktyka naszych parafii - przejmuje po rozwiązaniu się ich grupy kicrowanie inną grupą, tworzy nową grupę lub/i uczestniczy aktywnic w życiu wspólnoty parafialnej.

Faza śmierci grupy nie musi jednak pojawić się dopicro wtedy, gdy grupa przejdzic wszystkie kolejne stadia rozwoju. Do rozpadu grupy może dojśc w każdej fazie. Grupa może umrzeć, kiedy np. konflikty w niej nie dają się zalagodzić albo poszczególni jej członkowie mają zbyt różne oczekiwania, albo dotychczasowy lider musial

${ }^{40}$ Tamżc, s. 201. 
odejść, a ten nowy jest zupetnie inny itp. Grupa może się tcż rozwiązać, gdyż jej członkowie po prostu nie widzą już żadnych wspólnych zaintercsowań i cclów. Nie jest to dla nich latwa sytuacja, gdyż muszą się do tego otwarcic przyznać: Nie jestesmy juz sobie potrzebni; inni ludzie, inne cele stały się dla nas ważniejsze... Im szczerzcj o tym ze sobą rozmawiają, tym latwiej przychodzi im pogodzenie się z likwidacją grupy i koniecznością rozstania. Dobrze jest, gdy we wszystkich grupach (a więc nie tylko tych, które zostały założone w konkretnym celu i na określony czas, np. parafialne zespoły synodalnc) od samego początku temat końca gnupy nie stanowi tabu i poprzez reflcksję stale pozostaje w polu widzenia członków grupy. Ponicważ każde rozstanie w naszym życiu sprawia nam búl i często wiąże się z poczuciem winy, a nickiedy możc wrȩcz zagrażać naszcj egzystencji, powinnismy przez całe życie uczyć się pozytywnego odnoszenia się do takich doświadczeń. Grupa jest do tego doskonałym miejscem - zwłaszcza w swojej fazie końcowej.

W fazic rozstania bardzo ważne jest spojrzenie wstecz, na to wszystko, co się razem przeżylo i co się osiągnęlo: Jakq drogq szedlem? Jak czulem się posród innych w grupie? Jak oceniam ten wspólnie przeżyn czas?, pytanic o obecną sytuację: Gdzie się teraz znajduję? Co jest teraz dla mnie ważne?, a także rzut oka na najbliższą przyszłość: Jaki będzie mój następny krok? Z jakimi trudnosciami muszę się liczyć? Jak powinienem do nich podejśc? Co może mi w lym pomóc? Oczywiścic nie wszystko musi być wypowiedziane, ale rozmowa bardzo ulatwia poradzenic sobic $z$ dosiwiadczeniem rozstania. Lider grupy, który ma tutaj znowu ważną rolę do odegrania, powinicn zachęcać poszczególnych czlonków do aktywnego udziału w procesie akceptacji śmierci grupy $\mathrm{i}$ ich w tym wspierać. Chodzi o to, by nie pozostały w nich jakieś negatywne odczucia: Nie udalo mi się. Opuszczam kogos. Czuję się pozostawiony sobie samemu. Obawiam się, że cos jednak bylo nie tak...

Koniec grupy nie musi oznaczać zamierania więzi między poszczególnymi członkami. Z praktyki wiadomo, że niektórzy z nich spotykają się ze sobą regularnie jeszcze przez dlugie lata, tworząc coś w rodzaju grup wtómych.

W wielu naszych parafialnych grupach dziecięcych i mlodzieżowych ze względu na zmianę pokoleń, a przez to zmianę struktury grupy, koniec oznacza często nowy początek. Oto krótki opis takiej sytuacji: Niekıórzy poszli do wojska, inni mieli egza. miny $i$ nie przychodzili na spotkania. Po pewnym czasie, kiedy grupa skurczyła się do sześciu uczestników, Irudno było dhużej udawać, że wszystko jest w porzqdku. Ta szósıka niezmordowanych chciala - jak mówila - ratować grupę. Zaczęli więc szukać nowych czlonków. I udalo im się! Siedmiu młodych ludzi dołączyło do gnupy. Przez jakis czas szto niezle (...) Po czterech miesiącach nie wiadomo dlaczego kuloinito się» onych szesciu starszych. Po prostu odeszli, a ci mlodsi zaczęli pisać wlasną grupowa historię"! Ostatnic zdanie tej relacji wyraża istotną prawdę: dzicje każdej grupy są nicpowtarzalne; nowi czlonkowie piszą zawsze własną historiç.

"J. Griesbeck, dz. cyl., s. 67. 
Omawianiu poszczególnych faz procesu grupowego towarzyszyla analogia do chrześcijańskiej inicjacji. Podobnie jak ona rorwó żcia grupy jest procesem wzrastania, w którym czlowiek w swojej egzystencjalnej rzeczywistosci dązy do dojrzatosci, do pełni życia. W' grupie chrześcijańskiej tą pełnią jest Jezus Chrystus, który wzywa ludzi do tworzenia żyych wspólnot, do otwarcia się na Jego Ducha, do uczestnictwa w Jego życiu i do swiadczenia o tym $w$ apostolskim zaangażowanitu. W ten spośb ta wspólnota staje się sakramentem jedhótci, w której ochrzczeni ciągle na nowo pozwalają odżywać i roznfecać się udzielonej im lasce Bozej.

Ujawniająca się tu zbieżnośc między psychologicznymi i socjologicznymi prawami procesu dojrzewania grupy i praktyką Kościoła pierwotnego potwierdza słusznošc

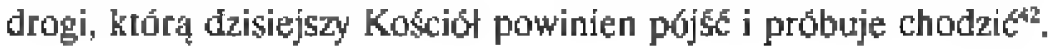

${ }^{42}$ Por. H. Mühlen: New mil Gort. Einübung in chringiches Lehen und Zeugnis. Freiburg 1990 s. $15-17$. 